\title{
Nontuberculous Mycobacterium infection complicated with Haemophagocytic syndrome: a case report and literature review
}

Wen Shi and Yang Jiao* (1)

\begin{abstract}
Background: Non-tuberculous mycobacterial (NTM) infection is usually observed in patients with immunosuppressive conditions. It may also cause unregulated immune responses. While there have been increasing numbers of reported tuberculosis-related HPS (haemophagocytic syndrome), HPS caused by NTM infection is still very rarely reported.

Case presentation: We report a previously healthy 21-year-old Chinese female with fever, night sweats and fatigue, in whom HPS was diagnosed according to the HLH-2004 criteria. Mycobacterium intracellulare was cultured from her peripheral blood. After treatment with corticosteroid, clarithromycin, rifampicin, ethambutol and amikacin, the patient finally recovered. We also reviewed relevant publications on NTM infection complicated with HPS and found 11 cases, including ours. Clinical presentations, diagnoses and prognoses were analysed and summarized to deepen our understanding of this rare condition.

Conclusions: Most reported NTM-related cases were caused by disseminated infection. The lack of localized symptoms might add to the difficulty involved in making the right diagnosis. While it usually takes time to obtain tissue or blood culture results, granuloma in a bone marrow biopsy might be an early indicator of possible mycobacterial infection. Although treatment varied, the overall prognosis of NTM-related HPS was promising.
\end{abstract}

Keywords: Nontuberculous Mycobacterium infection, Haemophagocytic syndrome, M. Intracellulare

\section{Background}

Haemophagocytic syndrome (HPS) is a rare, life-threatening condition characterized by over-stimulation of the immune system [1]. While primary HPS is genetically predisposed and usually develops during childhood and adolescence, secondary HPS can be triggered by a variety of conditions and may occur at any age [2]. The most common causes of HPS include viral infection, autoimmune disease and haematological malignancy [3]. On the one hand, NTM infection is usually observed in patients with immunosuppressive conditions $[4,5]$. On the other hand, it may cause intense immune responses. Although severe tuberculosis has been increasingly

\footnotetext{
* Correspondence: peterpumch@163.com

Department of General Internal Medicine, Peking Union Medical College Hospital, Chinese Academy of Medical Sciences \& Peking Union Medical College, No. 1, Shuaifuyuan, Wangfujing St, Beijing 100730, China
}

reported and recognized as a potential cause of HPS in recent years $[4,5]$, non-tuberculous mycobacterial (NTM) infection associated with HPS is still very rare. Here, we report a 21-year-old female who was diagnosed with HPS caused by disseminated Mycobacterium intracellulare infection where treatment of both NTM infection and HPS eventually led to recovery. We also performed a literature review of NTM infection complicated by HPS to deepen our understanding of the condition.

\section{Case presentation}

A 21-year-old female was admitted to our hospital complaining of fever and fatigue for 2 months. She was an editor and had been in good health until 2 months ago when she developed a spiking fever of $39-40^{\circ} \mathrm{C}$, dry cough, night sweats and fatigue. She went to a local hospital, and a complete blood count $(\mathrm{CBC})$ revealed only 
mild anaemia (Table 1). She was diagnosed with an "upper respiratory tract infection". Cefprozil was administered, but her symptoms gradually worsened, and a growing mass, which was painful, was found on the right side of her neck. She reported no arthralgia, rash, weight loss or relevant family history.

Her physical examination upon admission revealed scattered rales on the right lung, splenomegaly and enlarged lymph nodes that had coalesced and were palpated in her right cervical region. The initial laboratory investigation showed peripheral pancytopenia (white blood cells (WBC) $2.28^{*} 10^{9} / \mathrm{L}$, HGB $87 \mathrm{~g} / \mathrm{L}$, PLT $71^{*} 10^{9} /$ L, Table 1), elevated liver enzymes (ALT $192 \mathrm{U} / \mathrm{L}$, AST $139 \mathrm{U} / \mathrm{L}, \mathrm{LDH}$ 554 U/L) and hyperferritinaemia (Fer $4090 \mathrm{ng} / \mathrm{ml}$ ). Natural killer (NK) cell activity was tested via a flow cytometry-based assay previously reported by Zhang et al. and was found to be reduced [6]. Haemophagocytosis was found in the bone marrow aspirate (Fig. 1). Initial serological investigations for common pathogens and autoimmune diseases were negative (Table 1). A chest CT scan revealed bilateral nodules and right pleural effusion (Fig. 2), but Gram staining, acid-fast staining and mycobacterial culture of sputum were negative. An ultrasound-guided puncture was performed on her right cervical lymph nodes. Ziehl-Neelsen staining revealed acid-fast bacilli, and further nucleic acid probes identified M. intracellulare. Histology from the biopsied tissue showed inflammatory necrosis and calcification without evidence of malignancy. Then, $M$. intracellulare was cultured from her peripheral blood and lymph node tissue. We suspected that the patient might have autoantibodies against interferon- $\gamma$, which led to her immunosuppressive state and susceptibility to NTM infection. Unfortunately, serum testing for interferon- $\gamma$ autoantibody was not available in our hospital.

A regimen containing clarithromycin (500 mg BID po), rifampicin (450 mg QD po), ethambutol (750 mg QD po) and amikacin (0.4g QD iv) was started to treat the disseminated $M$. intracellulare infection. HPS was also diagnosed according to the HLH-2004 criteria, and prednisone $60 \mathrm{mg}$ QD po $(1 \mathrm{mg} / \mathrm{kg} / \mathrm{d})$ was given to control the inflammation.

Her temperature soon became normal. Prednisone was gradually tapered $(60 \mathrm{mg}$ QD*2 weeks $\rightarrow 40 \mathrm{mg} \quad$ QD*2 weeks $\rightarrow 20 \mathrm{mg}$ QD*2 weeks $\rightarrow \downarrow 5 \mathrm{mg} / 2$ weeks until stop), and amikacin was stopped after 1 month, while clarithromycin, rifampicin and ethambutol were continued. She was in remission, and her cervical lymph nodes were

Table 1 Laboratory results of our case

\begin{tabular}{|c|c|c|c|c|}
\hline & First visit & First day after admission & 1 week after admission & 6-month follow-up \\
\hline WBC $\left({ }^{*} 10^{9} / L\right)$ & 4.36 & 2.28 & 1.02 & 3.45 \\
\hline NEUT $\left(* 10^{9} / \mathrm{L}\right)$ & 3.66 & 1.77 & 0.71 & 2.87 \\
\hline $\mathrm{HGB}(\mathrm{g} / \mathrm{L})$ & 91 & 87 & 59 & 112 \\
\hline $\operatorname{PLT}\left({ }^{*} 10^{9} / \mathrm{L}\right)$ & 109 & 71 & 51 & 141 \\
\hline $\operatorname{ALT}(U / L)$ & & 192 & & 7 \\
\hline AST (U/L) & & 139 & & 11 \\
\hline $\mathrm{LDH}(\mathrm{U} / \mathrm{L})$ & & 554 & & \\
\hline $\operatorname{Cr}(\mu \mathrm{mol} / \mathrm{L})$ & & 89 & & 69 \\
\hline $\mathrm{ESR}(\mathrm{mm} / \mathrm{h})$ & & $>140$ & & \\
\hline hsCRP (mg/L) & & 174 & & 7.9 \\
\hline Triglyceride (mmol/L) & & 2.62 & & \\
\hline Fibrinogen (g/L) & & 3.5 & & \\
\hline Fer (ng/ml) & & 4090 & & \\
\hline B cell $(/ \mu l)$ & & 7 & & 56 \\
\hline T cell $(/ \mu l)$ & & 233 & & 459 \\
\hline NK cell $(/ \mu \mathrm{l})$ & & 6 & & 89 \\
\hline Other & \multicolumn{4}{|c|}{$\begin{array}{l}\text { CMV-DNA, EBV-DNA, CMV-IgM, CMV-pp65, HIV antibody, T.SPOT-TB(-) } \\
\text { ANA, ANCA, anti-RNP, anti-Sm, anti-SSA, anti-SSB, anti-rRNP, anti-Scl-70, anti-Jo-1, anti-PM-Scl, anti-dsDNA, anti-PCNA, ACA, } \\
\text { AMA-M2, anti-histone antibodies, anti-CCP, ACL, anti-B2GP1, LAC, Coombs(-) }\end{array}$} \\
\hline \multicolumn{5}{|c|}{$\begin{array}{l}\text { WBC, white blood cells; NEUT, neutrophils; HGB, haemoglobin; PLT, platelets; ALT, alanine aminotransferase; AST, aspartate aminotransferase; LDH, lactate } \\
\text { dehydrogenase; Cr, creatinine; ESR, erythrocyte sedimentation rate; hsCRP, high-sensitivity C-reactive protein; Fer, ferritin; SF, serum ferritin; ANA, antinuclear } \\
\text { antibody; ANCA, antineutrophil cytoplasmic antibodies; T.SPOT-TB, interferon-gamma release assay T.SPOT-TB; anti-RNP, anti-ribonucleoprotein antibodies; anti-Sm, } \\
\text { anti-Smith antibody; anti-SSA, anti-Sjögren syndrome A antibody; anti-SSB, anti-Sjögren syndrome B antibody; anti-rRNP, anti-ribosomal RNP antibodies; anti-Scl- } \\
\text { 70, anti-Scl-70 antibody; anti-dsDNA, anti-double-stranded-DNA antibody; anti-Jo-1, anti-Jo-1 antibody; anti-PM-SCl, anti-exosome antibodies; anti-PCNA, anti- } \\
\text { proliferating-cell-nuclear-antigen antibody; ACA, anticentromere antibody; AMA-M2, antimitochondrial antibody M2 subtype; CCP, cyclic citrullinated peptide; ACL, } \\
\text { anti-cardiolipid antibody; } \beta 2 G P 1, ~ \beta 2-\text {-glycoprotein I; LAC, lupus anti-coagulant }\end{array}$} \\
\hline
\end{tabular}




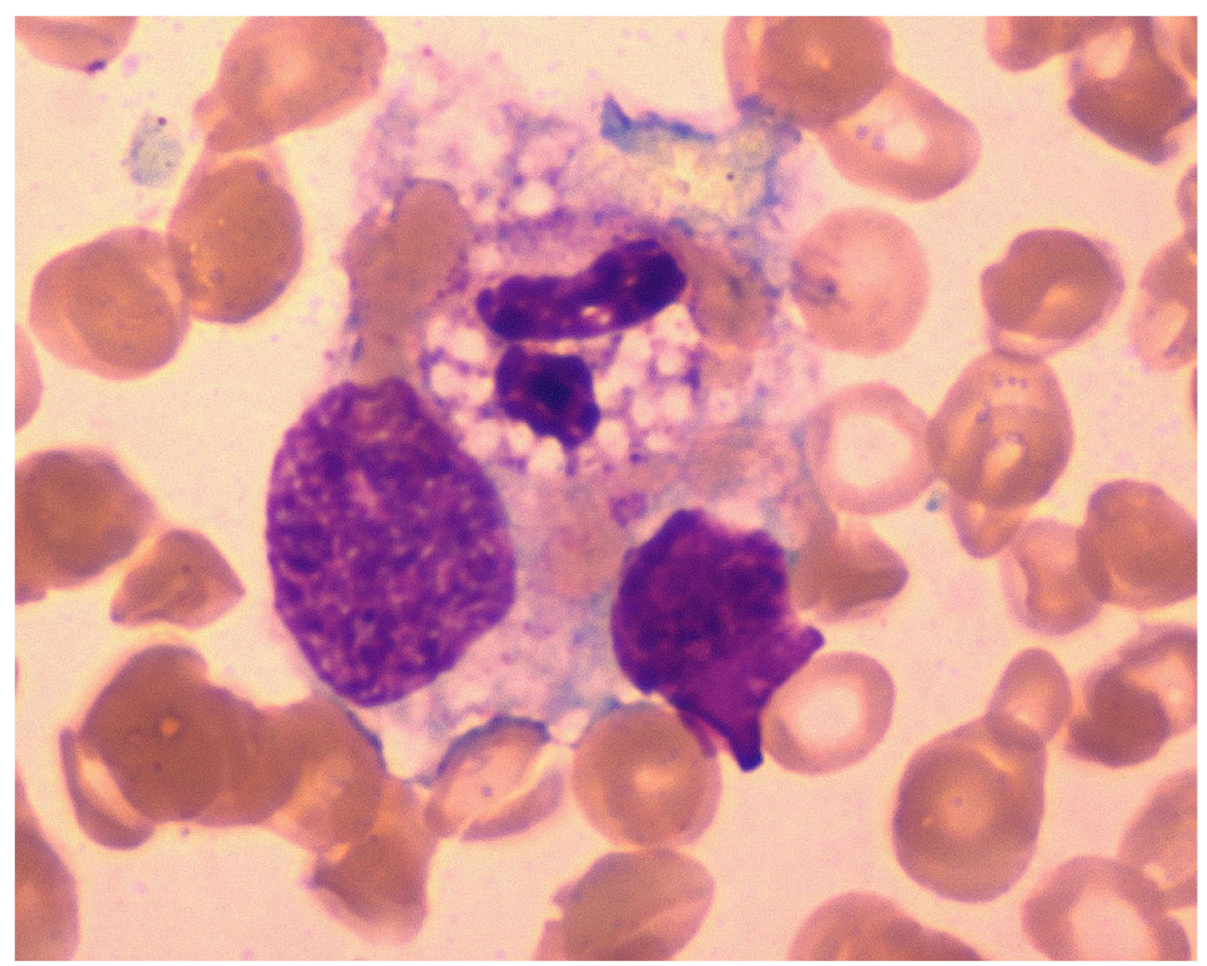

Fig. 1 Bone marrow aspirate specimen showed a haemophagocyte engulfing a polymorphonuclear leukocyte, a lymphocyte and erythrocytes (Wright-Giemsa stain, 1000x)

unpalpable with normal $\mathrm{CBC}$ at the 6-month follow-up visit. The patient was then lost to follow-up.

\section{Literature review}

We then searched PubMed for cases of NTM infection complicated with HPS (see Appendix for detailed search strategy) and found 10 case reports in addition to ours (Table 2).

All patients except ours were found to have concomitant immunosuppressive conditions: 1 with AIDS, 2 with autoimmune diseases (1 systemic lupus (SLE) and 1 Sweet's syndrome, both taking immunosuppressive agents), 1 who had undergone an organ transplantation, 1 with sickle cell anaemia and 4 with haematological malignancies (1 acute lymphoblastic leukaemia (ALL), 1 chronic lymphocytic leukaemia (CLL), 1 myelodysplastic syndrome (MDS) + GATA2 gene mutation and 1 Hodgkin's lymphoma). One patient was found to have advanced femoral sarcoma 5 months after NTM infection, and HPS was diagnosed.

Most patients (9/11) definitely had disseminated NTM infections. In case 7 , however, although the M. avium complex was cultured only from gastric lavage and blood culture was negative, non-caseating granulomatosis was found in a bone marrow biopsy, indicating that this might be a disseminated $M$. avium complex infection. Similar to our patient, all patients reported constitutional symptoms (fever, night sweats, weight loss, fatigue, etc.) as their main complaints. Other symptoms were rather vague and nonspecific except in case 10, where the patient was found to have rashes, and skin biopsy culture revealed $M$. abscessus.

For pathogenic NTM infection, M. avium complex (including $M$. intracellulare in our patient) was found in 5 patients, M. kansasii in 4 patients, M. lentiflavum in 1 patient, $M$. iranicum in 1 patient and $M$. abscessus in 1 patient.

Like our patient, most patients (9/11) were first suspected of having and diagnosed with HPS before NTM infection was revealed in blood or tissue specimens. The exceptions included case 3, whose faecal specimen had positive $M$. lentiflavum PCR results but was left untreated until HPS developed when the patient was re-evaluated, and case 6 , who had been treated for $M$. avium complex infection but later deteriorated with the development of HPS. Interestingly, 5/11 patients were found to have granuloma in the bone marrow specimen before NTM infection finally developed from concomitant blood or tissue specimen culture.

Treatment varied considerably. Corticosteroid, etoposide, cyclosporin A (CsA) and intravenous immunoglobulin (IVIG) were administered in different combinations to treat HPS in most patients. Case 6 was also treated with anakinra in addition to corticosteroids. Antibiotics were added to treat NTM infection and adjusted according to 

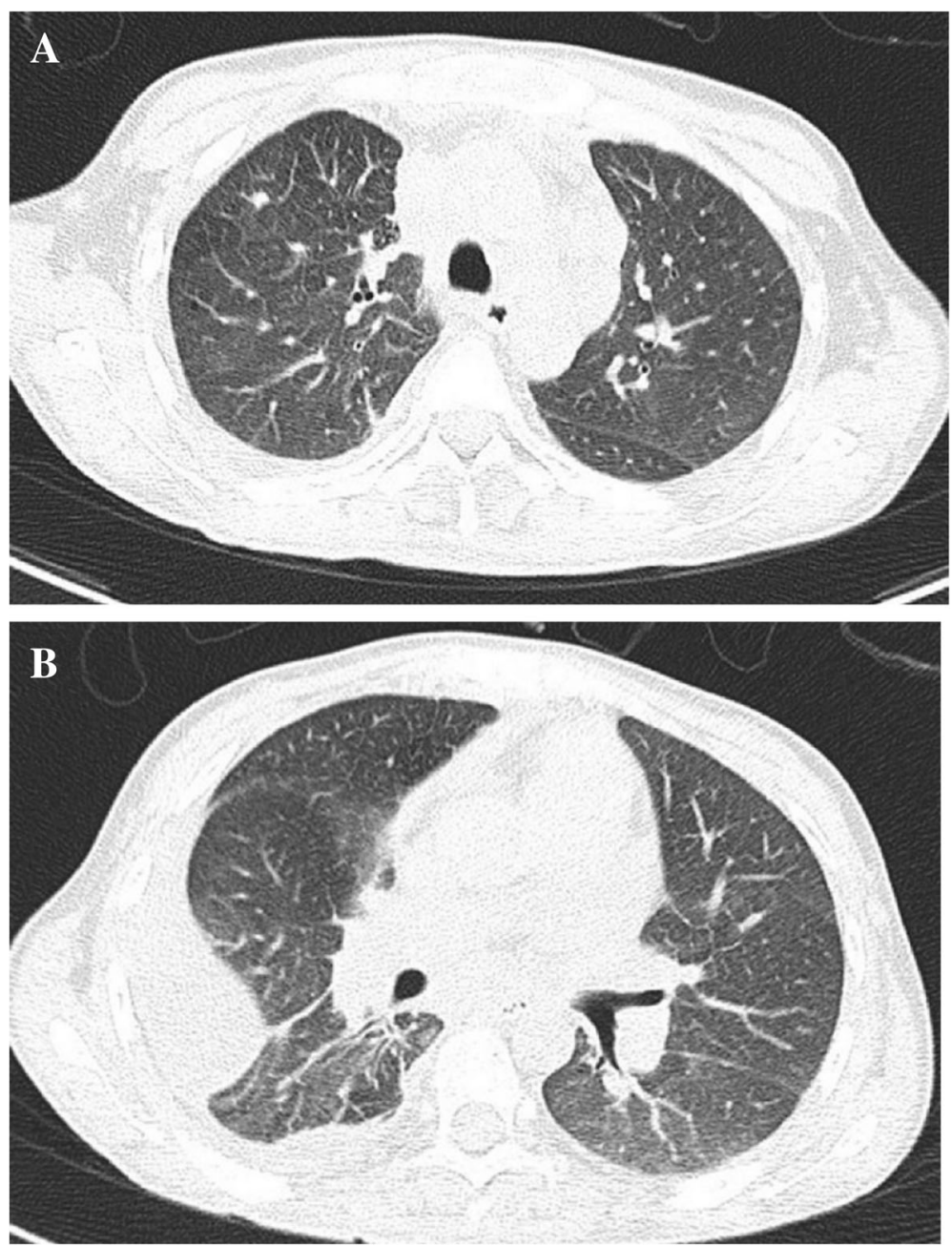

Fig. 2 (a) Chest CT scan revealed scattered nodules and (b) right pleural effusion

speciation. There were, however, 2 exceptions. Case 5 had been diagnosed with acquired immune deficiency syndrome (AIDS) and started highly active antiretroviral therapy (HAART) 3 weeks before disseminated M. avium complex and histoplasmosis complicated with HPS were diagnosed. Immunosuppressive therapy was not added for HPS, but antimycobacterial and anti-fungal drugs were used as well as HAART. The patient eventually recovered. Case 8 was diagnosed as disseminated $M$. iranicum infection complicated by HPS. Lymph node biopsy revealed a stage IV Hodgkin's disease at the same time. Since his $M$. iranicum was multidrug-resistant, he was treated only with bleomycin, etoposide, adriamycin, cyclophosphamide, oncovorin, procarbazine and prednisone (BEACOPP) for his HPS and Hodgkin disease. The patient also recovered. The prognoses of patients with reported NTM infection complicated with HPS were relatively good: 2/11 died, while $9 / 11$ survived. In case 4 , the correct diagnosis of
NTM infection as the cause of HPS instead of ALL relapse even prevented haematopoietic stem cell transplantation.

\section{Discussion and conclusions}

NTM infection is caused by generally free-living organisms that are ubiquitous in the environment [7]. With the development of new microbiological methods, NTM infection in human diseases has become increasingly recognized and reported [8]. M. avium complex and $M$. kansasii are believed to be the most common species [9], which is in accordance with our literature review results. On the one hand, NTM infection, especially disseminated NTM infection, is usually observed in patients with immunosuppressive conditions [9]; on the other hand, NTM infection can trigger HPS, a strong and uncontrolled immune response. Our literature review found 11 cases (including ours) in total indicating that the correlation is still rarely reported, and all cases 
Table 2 Published cases of NTM infection complicated with HPS

\begin{tabular}{|c|c|c|c|c|c|c|c|c|c|c|}
\hline & $\begin{array}{l}\text { Author } \\
\text { Country } \\
\text { Year }\end{array}$ & $\begin{array}{l}\text { Sex/ } \\
\text { Age }\end{array}$ & Symptoms & $\begin{array}{l}\text { Cause of } \\
\text { NTM infection }\end{array}$ & Method & $\begin{array}{l}\text { Infection } \\
\text { location }\end{array}$ & $\begin{array}{l}\text { Underlying } \\
\text { disease }\end{array}$ & Treatment & Prognosis & $\begin{array}{l}\text { BM } \\
\text { pathology } \\
\text { showing } \\
\text { granuloma }\end{array}$ \\
\hline 1 & $\begin{array}{l}\text { D. Har/ } \\
\text { USA, } \\
2017 \text { [12] }\end{array}$ & $M / 58$ & $\begin{array}{l}\text { Fever, night } \\
\text { sweats, } \\
\text { wt loss }\end{array}$ & M. kansasii & $\begin{array}{l}\text { Spleen } \\
\text { biopsy } \\
\text { culture }\end{array}$ & $\begin{array}{l}\text { Isolated } \\
\text { spleen lesion }\end{array}$ & $\begin{array}{l}\text { Sweet's } \\
\text { syndrome, } \\
\text { adalimub } \\
\text { ( } 2 \text { years) }\end{array}$ & $\begin{array}{l}\text { Dexamethasone, } \\
\text { etoposide, RIPE }\end{array}$ & Death & $\begin{array}{l}\text { Not } \\
\text { mentioned }\end{array}$ \\
\hline 2 & $\begin{array}{l}\text { Chou/ } \\
\text { PRC, } \\
2010 \text { [13] }\end{array}$ & $\mathrm{F} / 60$ & $\begin{array}{l}\text { Fever, } \\
\text { postprandial } \\
\text { nausea, } \\
\text { vomiting }\end{array}$ & M. kansasii & $\begin{array}{l}\text { BM culture, } \\
\text { liver biopsy } \\
\text { culture }\end{array}$ & Disseminated & $\begin{array}{l}\text { Femoral } \\
\text { sarcoma } \\
\text { ( } 5 \text { months later) }\end{array}$ & $\begin{array}{l}\text { Methylprednisolone, } \\
\text { IVIG, RIPE, } \\
\text { azithromycin }\end{array}$ & Recovery & Yes \\
\hline 3 & $\begin{array}{l}\text { Thomas/ } \\
\text { France } \\
2014[14]\end{array}$ & $M / 65$ & $\begin{array}{l}\text { Fever, } \\
\text { wt loss, } \\
\text { diarrhoea }\end{array}$ & M. lentiflavum & $\begin{array}{l}\text { Blood } \\
\text { culture, } \\
\text { faecal } \\
\text { culture, } \\
\text { BALF, liver } \\
\text { autopsy }\end{array}$ & Disseminated & $\begin{array}{l}\text { Heart } \\
\text { transplantation, } \\
\text { tacrolimus } \\
\text { +MMF }\end{array}$ & $\begin{array}{l}\text { Prednisone, CsA, } \\
\text { MMF; rifabutin, } \\
\text { ethambutol, } \\
\text { clarithromycin, } \\
\text { amikacin }\end{array}$ & Death & Yes \\
\hline 4 & $\begin{array}{l}\text { Ordaya/ } \\
\text { USA, } \\
2017 \text { [15] }\end{array}$ & $F / 26$ & $\begin{array}{l}\text { Fever, } \\
\text { fatigue, } \\
\text { sore throat }\end{array}$ & $\begin{array}{l}\text { M. avium } \\
\text { complex }\end{array}$ & $\begin{array}{l}\text { Blood } \\
\text { culture }\end{array}$ & Disseminated & $\begin{array}{l}\text { ALL in } \\
\text { remission }\end{array}$ & $\begin{array}{l}\text { Dexamethasone, } \\
\text { etoposide, rifabutin, } \\
\text { ethambutol, } \\
\text { clarithromycin }\end{array}$ & $\begin{array}{l}\text { Recovery (stop } \\
\text { transplantation) }\end{array}$ & Yes \\
\hline 5 & $\begin{array}{l}\text { Hilmers/ } \\
\text { USA, } \\
2013 \text { [16] }\end{array}$ & $M / 40$ & Fever & $\begin{array}{l}\text { M. avium } \\
\text { complex }\end{array}$ & $\begin{array}{l}\text { Blood } \\
\text { culture, } \\
\text { BALF, BM } \\
\text { culture }\end{array}$ & Disseminated & $\begin{array}{l}\text { AIDS, HAART } \\
\text { ( } 3 \text { weeks, } \\
\text { histoplasmosis) }\end{array}$ & $\begin{array}{l}\text { Azithromycin, } \\
\text { ethambutol, } \\
\text { rifabutin, antifungal, } \\
\text { HAART }\end{array}$ & Recovery & $\begin{array}{l}\text { Not } \\
\text { mentioned }\end{array}$ \\
\hline 6 & $\begin{array}{l}\text { Chamsi- } \\
\text { Pasha/ } \\
\text { USA, } \\
2013 \text { [17] }\end{array}$ & $F / 22$ & $\begin{array}{l}\text { Fever, night } \\
\text { sweats, } \\
\text { wt loss }\end{array}$ & $\begin{array}{l}\text { M. avium } \\
\text { complex }\end{array}$ & $\begin{array}{l}\text { Lung } \\
\text { biopsy } \\
\text { culture, } \\
\text { blood } \\
\text { culture, BM } \\
\text { culture }\end{array}$ & Disseminated & $\begin{array}{l}\text { Sickle cell } \\
\text { anaemia }\end{array}$ & $\begin{array}{l}\text { Azithromycin, } \\
\text { ethambutol, } \\
\text { rifampin, } \\
\text { methylprednisolone, } \\
\text { anakinra }\end{array}$ & Death & Yes \\
\hline 7 & $\begin{array}{l}\text { Yang/ } \\
\text { PRC, } \\
2003[18]\end{array}$ & $F / 15$ & $\begin{array}{l}\text { Fever, } \\
\text { lethargy }\end{array}$ & $\begin{array}{l}\text { M. avium } \\
\text { complex }\end{array}$ & $\begin{array}{l}\text { Gastric } \\
\text { lavage }\end{array}$ & Disseminated & $\begin{array}{l}\text { SLE (prednisone } \\
+\mathrm{HCQ})\end{array}$ & $\begin{array}{l}\text { IVIG, etoposide; } \\
\text { clarithromycin, } \\
\text { ciproflaxcin, } \\
\text { amikacin }\end{array}$ & Recovery & Yes \\
\hline 8 & $\begin{array}{l}\text { Lapierre/ } \\
\text { France, } \\
2017 \text { [19] }\end{array}$ & $M / 55$ & $\begin{array}{l}\text { Fever, } \\
\text { wt loss }\end{array}$ & $\begin{array}{l}\text { M. iranicum } \\
\text { (multidrug- } \\
\text { resistant) }\end{array}$ & $\begin{array}{l}\text { Blood } \\
\text { culture }\end{array}$ & Disseminated & $\begin{array}{l}\text { Hodgkin's } \\
\text { disease } \\
\text { (at the } \\
\text { same time) }\end{array}$ & $\begin{array}{l}\text { Corticosteroid, } \\
\text { BEACOPP }\end{array}$ & Recovery & $\begin{array}{l}\text { Not } \\
\text { mentioned }\end{array}$ \\
\hline 9 & $\begin{array}{l}\text { M.I/ } \\
\text { Japan, } \\
2018 \text { [20] }\end{array}$ & $M / 14$ & $\begin{array}{l}\text { Fever, } \\
\text { wt loss }\end{array}$ & M. kansasii & $\begin{array}{l}\text { Blood } \\
\text { culture, } \\
\text { BM culture }\end{array}$ & Disseminated & $\begin{array}{l}\text { MDS (3 years), } \\
\text { GATA2 } \\
\text { heterozygous } \\
\text { mutation }\end{array}$ & $\begin{array}{l}\text { Prednisone, } \\
\text { etoposide, CSA, RIPE, } \\
\text { transplant }\end{array}$ & Recovery & No \\
\hline 10 & $\begin{array}{l}\text { Katagiri/ } \\
\text { Japan, } \\
2014[21]\end{array}$ & $M / 58$ & Fever, rash & M. abscessus & $\begin{array}{l}\text { Blood } \\
\text { culture, } \\
\text { skin }\end{array}$ & Disseminated & $\begin{array}{l}\text { CLL (prednisone } \\
+ \text { CTX) }\end{array}$ & $\begin{array}{l}\text { Imipenem, amikacin, } \\
\text { clarithromycin, } \\
\text { levofloxacin, IVIG }\end{array}$ & Recovery & No \\
\hline 11 & Our case & $F / 21$ & $\begin{array}{l}\text { Fever, } \\
\text { night } \\
\text { sweats, } \\
\text { fatigue }\end{array}$ & $\begin{array}{l}\text { M. } \\
\text { intracellulare }\end{array}$ & $\begin{array}{l}\text { Blood } \\
\text { culture, } \\
\text { lymph } \\
\text { node }\end{array}$ & Disseminated & No & $\begin{array}{l}\text { Clarithromycin, } \\
\text { rifampicin, } \\
\text { ethambutol, } \\
\text { amikacin, prednisone }\end{array}$ & Recovery & No \\
\hline
\end{tabular}

BM: Bone marrow; wt: weight; R: rifampin; I: isoniazid; P: pyramide, E: ethambutol; IVIG: intravenous immunoglobin; BALF: bronchoalveolar lavage fluid; MMF: mycophenolate; CSA: cyclosporin A; HAART: highly active antiretroviral therapy; BEACOPP: bleomycin, etoposide, adriamycin, cyclophosphamide, oncovorin, procarbazine and prednisone; MDS: myelodysplastic syndromes; GATA2: GATA-binding factor 2 gene; CLL: chronic lymphocytic leukaemia

were reported after 2010. However, secondary HPS is often associated with intracellular bacteria that induce classical Th1 immune responses, which, in animal models, are needed for the control of tuberculosis infection [10]. This might also be the reason why NTM infection can cause HPS.
Most of the reported patients, including ours, had disseminated NTM infection. All patients except ours had known underlying immune-compromised conditions. Our initial evaluation of the patient's immune state showed that the counts of B cells, T cells and NK cells were all decreased, while serum immunoglobulin levels 
were within normal ranges. After treatment, the patient's $\mathrm{B}$ cell, $\mathrm{T}$ cell and NK cell counts gradually rose. Thus, we doubt the decreases in the patient's lymphocytes and NK cells might be the result, rather than the cause, of her NTM infection. However, we cannot rule out the possibility that our patient might have undiscovered immunosuppressive conditions. Interestingly, case 2 was found to have advanced femoral sarcoma 5 months after being diagnosed with NTM infection and HPS. However, our patient was lost to follow-up 6 months later, and a more thorough investigation of possible underlying diseases, for example, malignancy, was not performed. As mentioned before, serum testing for interferon- $\gamma$ autoantibody was not available in our hospital until recently. Thus, we were not able to verify our suspicions before the patient was discharged and then lost to follow-up. Therefore, it is recommended that patients who are diagnosed with NTM infection complicated by HPS are carefully investigated to determine possible concomitant immune-compromised conditions.

M. intracellulare was grown from both the blood and cervical lymph node biopsy tissue cultures of our patient. Her chest CT scan also revealed bilateral nodules and right pleural effusion, indicating possible pulmonary involvement, even though no pathogens were successfully grown from the patient's sputum. No other focus of NTM involvement was found. $M$. intracellulare is reported to exist naturally in the environment, and the lung is the most common organ involved in M. intracellulare infection. Thus, we suspect that the port of entry of the mycobacteraemia might be from the respiratory tract, as is usually seen in patients with disseminated $M$. intracellulare infection. All patients reported constitutional symptoms as major complaints, which was in accordance with the fact that most cases were disseminated and lacked specific localized symptoms. In the majority of patients, HPS was suspected and diagnosed before NTM infection was detected and speciated. Interestingly, nearly half of the patients were found to have granuloma from bone marrow biopsy, which Is usually a routine examination when HPS is suspected. This biopsy finding could often be revealed earlier than the culture result, making it a promising positive predictor of disseminated mycobacterial (TB [11] or NTM) infection as the cause of HPS. In immunocompromised patients, HPS plus granuloma from bone marrow biopsy might justify a more thorough investigation and suspicion of possible mycobacterial infection.

Although treatment varied considerably, especially for HPS, the overall prognoses of NTM infection complicated with HPS seemed promising. Eight out of 11 patients recovered after treatment, and the correct diagnosis of NTM infection as the cause of HPS instead of ALL relapse even prevented haematopoietic stem cell transplantation in 1 patient, further indicating the importance of timely diagnosis of NTM infection complicated with HPS and starting treatment as soon as possible.

In conclusion, NTM infection is a rare cause of secondary HPS. Here, we report a 21-year-old female with disseminated $M$. intracellulare infection complicated by HPS who was successfully treated with antibiotics and corticosteroid. We reviewed relevant publications of NTM infection with HPS. Most reported NTM-related cases were caused by disseminated infection. Lack of localized symptoms might add to the difficulty involved in making the right diagnosis. While it usually takes time to obtain tissue or blood culture results, granuloma in a bone marrow biopsy might be an early indicator of possible mycobacterial infection. Although treatments varied, when patients were treated in a timely manner with antibiotics and anti-inflammation therapy, the overall prognosis of NTM-related HPS was promising.

\section{Abbreviations}

ACA: Anticentromere antibody; ACL: Anti-cardiolipid antibody;

AIDS: Acquired immune deficiency syndrome; ALL: Acute lymphoblastic leukaemia; ALT: Alanine aminotransferase; AMA-M2: Antimitochondrial antibody M2 subtype; ANA: Antinuclear antibody; ANCA: Antineutrophil cytoplasmic antibodies; Anti-dsDNA: Anti-double-stranded-DNA antibody; Anti-Jo-1: Anti-Jo-1 antibody; Anti-PCNA: Anti-proliferating-cell-nuclearantigen antibody; Anti-PM-Scl: Anti-exosome antibodies; Anti-RNP: Antiribonucleoprotein antibodies; Anti-rRNP: Anti-ribosomal RNP antibodies; AntiScl-70: Anti-Scl-70 antibody; Anti-Sm: Anti-Smith antibody; Anti-SSA: AntiSjögren syndrome A antibody; Anti-SSB: Anti-Sjögren syndrome B antibody; AST: Aspartate aminotransferase; BALF: Bronchoalveolar lavage fluid; BEACOPP: Bleomycin, etoposide, adriamycin, cyclophosphamide, oncovorin, procarbazine and prednisone; BM: Bone marrow; CBC: Complete blood count; CCP: Cyclic citrullinated peptide; CLL: Chronic lymphocytic leukaemia; Cr: Creatinine; CsA: Cyclosporin A; E: Ethambutol; ESR: Erythrocyte sedimentation rate; Fer: Ferritin; GATA2: GATA-binding factor 2 gene; HAART: Highly active antiretroviral therapy; HGB: Haemoglobin; HLH: Haemophagocytic lymphohistiocytosis; HPS: Haemophagocytic syndrome; hsCRP: High-sensitivity C-reactive protein; I: Isoniazid;

iv: Intravenous; IVIG: Intravenous immunoglobulin; LAC: Lupus anti-coagulant; LDH: Lactate dehydrogenase; $M$. abscessus: Mycobacterium abscessus; $M$. avium complex: Mycobacterium avium complex; $M$.

intracellulare: Mycobacterium intracellulare; M. iranicum: Mycobacterium iranicum; M. kansasii: Mycobacterium kansasii; M. lentiflavum: Mycobacterium lentiflavum; MDS: Myelodysplastic syndrome; MMF: Mycophenolate;

NEUT: Neutrophils; NK: Natural killer; NTM: Non-tuberculous mycobacterial; P: Pyramide; PCR: Polymerase chain reaction; PLT: Platelets; R: Rifampin; SF: Serum ferritin; SLE: Systemic lupus; T.SPOT-TB: Interferon-gamma release assay T.SPOT-TB; WBC: White blood cells; wt: Weight; $\beta 2$ GP1: $\beta 2$-glycoprotein

\section{Acknowledgements}

We thank Dr. Wei Cao in the Department of Infectious Diseases and Dr. Xinxin Cao in the Department of Hematology, Peking Union Medical College Hospital, for their assistance in the diagnosis of non-tuberculous mycobacterial and haemophagocytic syndrome.

Funding

Not applicable.

\section{Availability of data and materials}

All data generated or analysed during this study are included in this published article and its supplementary information files. 


\section{Authors' contributions}

Both authors were involved in the care of the patients. WS wrote the initial draft of the manuscript. YJ critically appraised and revised the overall content of the manuscript. All authors read and approved the final manuscript.

\section{Authors' information}

Both authors are from the Department of General Internal Medicine, Peking Union Medical College Hospital, Chinese Academy of Medical Sciences \& Peking Union Medical College, Beijing, China.

\section{Ethics approval and consent to participate}

Our study has been granted an exemption from review by the Institutional Review Board of Peking Union Medical College Hospital.

\section{Consent for publication}

Written informed consent was obtained from the patient for publication of this case report and any accompanying images.

\section{Competing interests}

The authors declare that they have no competing interests.

\section{Publisher's Note}

Springer Nature remains neutral with regard to jurisdictional claims in published maps and institutional affiliations.

Received: 23 February 2019 Accepted: 1 May 2019

Published online: 09 May 2019

\section{References}

1. Hayden A, Park S, Giustini D, Lee AY, Chen LY. Hemophagocytic syndromes (HPSs) including hemophagocytic lymphohistiocytosis (HLH) in adults: a systematic scoping review. Blood Rev. 2016:30(6):411-20.

2. Henter II, Horne A, Arico M, Egeler RM, Filipovich AH, Imashuku S, Ladisch S, McClain K, Webb D, Winiarski J, et al. HLH-2004: diagnostic and therapeutic guidelines for hemophagocytic lymphohistiocytosis. Pediatr Blood Cancer. 2007:48(2):124-31.

3. Morimoto A, Nakazawa Y, Ishii E. Hemophagocytic lymphohistiocytosis: pathogenesis, diagnosis, and management. Pediatrics international : official journal of the Japan Pediatric Society. 2016;58(9):817-25.

4. Chen L, Weng H, Li H, Huang J, Pan J, Huang Y, Ma C. Potential killer in the ICU-severe tuberculosis combined with hemophagocytic syndrome: a case series and literature review. Medicine. 2017;96(49):e9142.

5. Aggarwal P, Kumar G, Dev N, Kumari P. Haemophagocytic lymphohistiocytosis: a cause for rare but fatal outcome in tuberculosis. BMJ case reports. 2012;2012.

6. Zhang J, Wang Y, Wu L, Wang J, Tang R, Li S, Chen J, Gao Z, Pei R, Wang Z. Application of an improved flow cytometry-based NK cell activity assay in adult hemophagocytic lymphohistiocytosis. Int J Hematol. 2017; 105(6):828-34

7. Gruft H, Falkinham JO 3rd, Parker BC. Recent experience in the epidemiology of disease caused by atypical mycobacteria. Rev Infect Dis. 1981:3(5):990-6.

8. Griffith DE, Aksamit T, Brown-Elliott BA, Catanzaro A, Daley C, Gordin F, Holland SM, Horsburgh R, Huitt G, lademarco MF, et al. An official ATS/IDSA statement: diagnosis, treatment, and prevention of nontuberculous mycobacterial diseases. Am J Respir Crit Care Med. 2007;175(4):367-416.

9. Henkle E, Hedberg K, Schafer S, Novosad S, Winthrop KL. Population-based incidence of pulmonary nontuberculous mycobacterial disease in Oregon 2007 to 2012. Annals of the American Thoracic Society. 2015;12(5):642-7.

10. Jung YJ, Ryan L, LaCourse R, North RJ. Properties and protective value of the secondary versus primary T helper type 1 response to airborne Mycobacterium tuberculosis infection in mice. J Exp Med. 2005;201(12): $1915-24$

11. Asaji M, Tobino K, Murakami K, Goto Y, Sueyasu T, Nishizawa S, Yoshimine $K$, Munechika M, Ko Y, Yoshimatsu Y, et al. Miliary tuberculosis in a young woman with Hemophagocytic syndrome: a case report and literature review. Internal medicine (Tokyo, Japan). 2017:56(12):1591-6.

12. Har D, Wysocki C. A complicated case of mycobacterium kansasiitriggered hemophagocytic lymphohistiocytosis in the setting of immunosuppression. Ann Allergy Asthma Immunol. 2017;119(5 Supplement 1):S65-6.
13. Chou YH, Hsu MS, Sheng WH, Chang SC. Disseminated Mycobacterium kansasii infection associated with hemophagocytic syndrome. International journal of infectious diseases : IJID : official publication of the International Society for Infectious Diseases. 2010;14(3):e262-4.

14. Thomas G, Hraiech S, Dizier S, Weiller PJ, Ene N, Serratrice J, Secq V, Ambrosi $P$, Drancourt M, Roch A, et al. Disseminated Mycobacterium lentiflavum responsible for hemophagocytic lymphohistocytosis in a man with a history of heart transplantation. J Clin Microbiol. 2014;52(8):3121-3.

15. Ordaya EE, Jarir SA, Yoo R, Chandrasekar PH. Hemophagocytic lymphohistiocytosis (HLH): elusive diagnosis of disseminated Mycobacterium avium complex infection. Germs. 2017:7(3):149-52.

16. Hilmers DC. Hemophagocytic Lymphohistiocytosis in a patient with recent initiation of HAART Coinfected with Mycobacterium avium complex and disseminated histoplasmosis: who is the culprit? Infect Dis Clin Pract. 2013; 21(6):389-91.

17. Chamsi-Pasha MA, Alraies MC, Alraiyes AH, Hsi ED. Mycobacterium avium complex-associated Hemophagocytic Lymphohistiocytosis in a sickle cell patient: an unusual fatal association. Case reports in hematology. 2013;2013: 291518

18. Yang WK, Fu LS, Lan JL, Shen GH, Chou G, Tseng CF, Chi CS. Mycobacterium avium complex-associated hemophagocytic syndrome in systemic lupus erythematosus patient: report of one case. Lupus. 2003;12(4): 312-6.

19. Grandjean Lapierre S, Toro A, Drancourt M: Mycobacterium iranicum bacteremia and hemophagocytic lymphohistiocytosis: a case report 2017, 10(1):372.

20. Eguchi K, Ishimura M. Nontuberculous mycobacteria-associated hemophagocytic lymphohistiocytosis in MonoMAC syndrome. Pediatr Blood Cancer. 2018;65(7):e27017.

21. Katagiri S, Yoshizawa S, Gotoh M, Nakamura I, Ohyashiki K. Case report; disseminated Mycobacterium abscessus infection with hemophagocytic syndrome during treatment of chronic lymphocytic leukemia. Nihon Naika Gakkai zasshi The Journal of the Japanese Society of Internal Medicine. 2014;103(3):734-7.

Ready to submit your research? Choose BMC and benefit from:

- fast, convenient online submission

- thorough peer review by experienced researchers in your field

- rapid publication on acceptance

- support for research data, including large and complex data types

- gold Open Access which fosters wider collaboration and increased citations

- maximum visibility for your research: over $100 \mathrm{M}$ website views per year

At BMC, research is always in progress.

Learn more biomedcentral.com/submissions 